\title{
FIRM COMPETITIVENESS OF MANUFACTURING INDUSTRY
}

\author{
D. Doncheva* \\ Department of Economics, Faculty of Economics, Trakia University, Stara Zagora, Bulgaria,
}

\begin{abstract}
The study of firm competitiveness allows to make an objective assessment of the economic results and the possibilities for increasing the level of competitiveness by highlighting the sources of competitive advantage of the respective company in the conditions of expanding competition in the domestic and international markets. This will allow for effective strategies to be developed and will reveal new opportunities for good long-term results. The aim of the paper is to apply a firm-level competitiveness approach and model for the Manufacturing sector identifying the main sources of competitive advantage that determine it. Biserial Correlation and Optimal Binning are used as a related method in this study for assessing firm competitiveness.
\end{abstract}

Key words: modeling of competitiveness, Biserial Correlation, Optimal Binning, financial statement analysis

\section{INTRODUCTION}

The economy today is characterized by processes of increased globalization, dynamics and hyper-competition between market entities in pursuit of high financial results, favorable image, and growth. In the struggle for scarce resources, hundreds of companies go bankrupt each year and new market entities emerge whose existence sometimes depends on the level of competitiveness achieved. Competitiveness predetermines corporate power and the ability to achieve higher economic and social effects. The study of firm competitiveness allows us to make an objective assessment of the economic results and opportunities for increasing the level of competitiveness by highlighting the sources of competitive advantage of the respective company in the conditions of expanding competition in domestic and international markets. This will allow effective strategies to be developed and will reveal new opportunities for good long-term results.

As an economic category competitiveness manifests itself on a product, firm, industry and national level in a cause-and-effect

*Correspondence to: Dora Doncheva, Ph.D., Department of Economics, Faculty of Economics, Trakia University, Stara Zagora, Bulgaria, 042/ 699 428, e-mail: dora.doncheva@trakia-uni.bg relationship interacting one with another. A competitive economy enables the development, prosperity and economic growth of industries, while competitive firms have the opportunity to invest and grow their businesses. So that, they could change the competitive structure of an industry and increase the standard of living of the population. Thus, firm-level competitiveness is a driving force for the progress of a national economy.

Competitiveness is a complex and multidimensional category and there are many definitions about its concept because of the scope, complexity and differences in the objectives of market entities and sources of competitive advantage at each level studied. Nevertheless, in general, many researchers (17) see a firm's competitiveness as a competition for achieving a better result than other competitors, by offering a better product, reaching a high market share, having more and better resources, attracting more customers, etc. Thus, it can be summarized that firm competitiveness cannot be measured by a single criterion. The various criteria are selected based on highlighting the strongest competitive advantages. The sources of competitive advantages are looking for individual key characteristics of the business or 
redistribution of market forces in order to find those advantages that most differentiate the companies from each other.

Competitiveness is directly related to the creation and maintenance of competitive advantages and their sources can be found both in the external and internal environments of the enterprise. In this sense, for the purposes of this study, it is assumed that competitive advantage is an advantage unique or difficult to recreate from competitors which allows the company to outperform its rivals, better position themselves in the market from others, and to achieve higher economic results and market share. Managers choose a development strategy based on the most effective sources of competitive advantages and at the same time they consider the changes occurred in the external environment and the internal capabilities and resources of the enterprise.

Based on all above-mentioned and a literature review made previous the firm competitiveness is considered as the ability for and dynamics of: increasing the market share of the company; creating and sustaining competitive advantages; to improve company efficiency, productivity and profitability; to react and act in a competitive environment through its financial strength; implementation of the company strategy against other companies operating in the same market. For the needs of this study firm competitiveness is define as the ability of companies, on the basis of created and/or acquired competitive advantages (result of company's characteristics owned resources and ongoing processes, and the influence of external conditions) to earn and maintain a sustainable market share and profit.

Competitiveness assessment is a serious 'case study' that is not subject to postponement considered in the context of industrial policy. In the last 30 years a steady tendency towards de-industrialization of the national economy has been observed in Bulgaria. A strategic issue for the re-industrialization of the national economy reflecting on micro-economic competitiveness was brought out in Bulgaria (8). From this point of view a systematic indepth study of the industrial enterprises' activities and the assessment of their competitiveness, as well as at the sectoral level, is crucial to improving their management and operation and will allow to reveal new opportunities for promotion of their competitive ability. Thus, emphasizes the need of a methodology for assessing competitive advantage which underpins the development of effective strategies and reveals new opportunities for good long-term results.

\section{MATERIAL AND METHODS}

The aim of the paper is to apply a firm-level competitiveness approach and model for Manufacturing sector identifying the main sources of competitive advantage that determine it.

The subject of the study is the competitiveness of large enterprises (employing over 250 people) in Manufacturing sector in the SouthEast region of Bulgaria (SER). The empirical study covers 45 large enterprises in the SouthEast region in the period 2010-2017, which represented $100 \%$ of all registered companies in the sector in the region.

The choice of Manufacturing sector is driven by the fact that the sector generates the highest added value at regional level. For comparison, the results from conducted another survey of 780 industrial companies (represents 5\% stratified sample of all companies operating in the country in the same period) confirmed the highest contribution of Manufacturing to Value Added (VA).

This fact necessitates of finding ways for both maintaining this position and revealing new opportunities for enhancing competitiveness and growth that can be specific to each company in the industry.

Manufacturing is a sub-sector of Industry - the second largest sector generating the most Gross Domestic Product (GDP), generating a significant share of Value Added in the SouthEast region which determines its importance for the regional economic development and raising the standard of living of the population. The period 2010-2017 is characterized by a dynamic condition driven mainly by the global economic crisis strike at the end of 2008 (6-8\% GDP growth) and the slow economic recovery thereafter. From 2010 to 2017 the Bulgarian economy recorded a small but positive GDP growth accelerating to $3.8 \%$ in 2017 compared with the average GDP growth of EU-28 $2.8 \%$.

The sectoral data presented in Table 1 clearly show the Industry contribution and in particular the Manufacturing one to the structure of Gross Value Added (GVA). The Industry creates $27-28 \%$ of GVA in Bulgaria for the reference period. 
Table 1. Percentage change in GVA by sectors between 2010 and 2017

\begin{tabular}{|l|l|l|l|l|}
\hline Countries & Bulgaria & EU - 28 \\
\hline Period & $\mathbf{2 0 1 7 / 2 0 1 6}$ & $\mathbf{2 0 1 7 / 2 0 1 0}$ & $\mathbf{2 0 1 7 / 2 0 1 6}$ & $\mathbf{2 0 1 7 / 2 0 1 0}$ \\
\hline Total (all NACE 2008 activities) & 7.90 & 34.8 & 2.80 & 19.4 \\
\hline Agriculture, forestry and fisheries (A) & 7.78 & 32.3 & 9.47 & 23.1 \\
\hline Industry (excluding Construction) (B-E) & 7.59 & 62.1 & 3.03 & 21.8 \\
\hline Manufacturing (C) & 8.75 & 69.4 & 3.27 & 26.7 \\
\hline Construction (F) & 13.42 & -14.9 & 5.22 & 11.5 \\
\hline Services (G-U) & 7.35 & 23.8 & 2.19 & 17.3 \\
\hline
\end{tabular}

Source: Own calculations based on National Accounts database, Eurostat

According to Eurostat data Industry has the highest contribution to the GVA for 2011, 2015, 2016 and 2017. The lowest levels were recorded in 2010 and 2013. Looking only at the Manufacturing it can be seen a similar increase in the contribution to GVA. The highest growth rates were recorded in 2011 and 2014-2017 and the lowest in 2010 and 2013. The most likely negative effects on the Industry's results are due to the global financial and economic crisis, shrinking consumption and the collapse in export. Considering only the results of the Industry, the South-East region has the largest share in generating of value added (46.26\% in 2017). As can be seen in the SER (Table 2), the second most contributing economic sector is the Industry which has a leading importance for the regional economy - $46.26 \%$ compared to the national average $-28.44 \%$.

Table 2. Structure of GVA by economic sectors in Bulgaria and SER for the period 2010-2017, \%

\begin{tabular}{|l|l|l|l|l|l|l|l|l|l|}
\hline \multirow{2}{*}{ Region } & $\begin{array}{l}\text { Economic } \\
\text { Sectors }\end{array}$ & $\mathbf{2 0 1 0}$ & $\mathbf{2 0 1 1}$ & $\mathbf{2 0 1 2}$ & $\mathbf{2 0 1 3}$ & $\mathbf{2 0 1 4}$ & $\mathbf{2 0 1 5}$ & $\mathbf{2 0 1 6}$ & $\mathbf{2 0 1 7}$ \\
\hline \multirow{3}{*}{ Bulgaria } & Agriculture, \% & 4,78 & 5,25 & 5,27 & 5,36 & 5,25 & 4,79 & 4,70 & 4,69 \\
\cline { 2 - 10 } & Industry, \% & 27,38 & 29,029 & 28,89 & 27,27 & 27,27 & 27,87 & 28,31 & 28,44 \\
\cline { 2 - 9 } & Services, \% & 67,84 & 65,46 & 65,84 & 67,37 & 67,48 & 67,34 & 66,99 & 66,87 \\
\hline \multirow{3}{*}{ SER } & Agriculture, \% & $\mathbf{5 , 6 2}$ & $\mathbf{6 , 3 4}$ & $\mathbf{6 , 1 7}$ & $\mathbf{6 , 1 8}$ & $\mathbf{6 , 1 1}$ & $\mathbf{5 , 7 0}$ & $\mathbf{5 , 2 4}$ & $\mathbf{5 , 4 6}$ \\
\cline { 2 - 9 } & Industry, \% & $\mathbf{3 9 , 4 3}$ & $\mathbf{4 0 , 3 9}$ & $\mathbf{4 2 , 0 4}$ & $\mathbf{4 0 , 9 9}$ & $\mathbf{4 2 , 2 9}$ & $\mathbf{4 1 , 7 2}$ & $\mathbf{4 6 , 5 0}$ & $\mathbf{4 6 , 2 6}$ \\
\cline { 2 - 9 } & Services, \% & $\mathbf{5 4 , 9 5}$ & $\mathbf{5 3 , 2 7}$ & $\mathbf{5 1 , 7 9}$ & $\mathbf{5 2 , 8 3}$ & $\mathbf{5 1 , 6 1}$ & $\mathbf{5 2 , 5 8}$ & $\mathbf{4 8 , 2 6}$ & $\mathbf{4 8 , 2 8}$ \\
\hline
\end{tabular}

Source: Own calculations based on National Accounts database, Eurostat

The relative share of SER in the total country's GDP after 2007 is characterized by sustainability at about $12 \%$ and the region remains third after the South-West and the South-Central regions.

The different sectors' contribution to GVA in SER to the country's GVA in 2017 has the following values: Agriculture and forestry sector forms $15.05 \%$, Industry forms $21.05 \%$, and Services $-9.34 \%$.

The large companies in Manufacturing (C) operates in SER generated $70-80 \%$ of the revenue in the region. In 2017 the number of non-financial companies operate in sector $\mathrm{C}$ in SER is 3989 which represented about $13 \%$ of all enterprises operate in Manufacturing in Bulgaria. The number of all large companies in SER operates in Manufacturing is 45 which represented $16 \%$ of the large enterprises in this sector in Bulgaria (287 in 2017). Typically, these enterprises accounted for about $58 \%$ of turnover in the sector and $35 \%$ of employment. There has been a steady increase in employment at about $6.5 \%$ on an average basis over the period 2010-2017 and significant growth in wage costs - over $76 \%$ on an average basis.

Achieving a certain level of competitiveness is a result of actions of many factors - a set of external and internal conditions for the economic unit that determines its economic performance and the level of its success relative to those of its competitors. The assessment of the individual factors of competitiveness impact at the firm level emphasizes on the sources of competitiveness and opportunities for their enhancement.

The main contradictory point about the firm competitiveness' concept is defining the content and scope of the final result. In many cases (9-29) competitiveness is considered as equal to product competitiveness or is 
identifying with productivity, higher profitability and efficiency than firm's rivals, with flexibility and adaptation to changing conditions, company's market share and growth, return on assets as a criterion for competitiveness.

After a thorough analysis of the literature related to competitiveness and competitive advantages for the purpose of this study the following factors were selected:

1) Internal competitiveness factors at the firm level - Market share growth; Profitability; Gross profit margin; Labour Productivity; Capital structure; Turnover of Total Assets; Innovation; Firm export; Total liquidity; Size; Age;

2) External factors of competitiveness - GDP growth (\% annual growth); Country's Export (\% annual growth); FDI (net outflows, $\%$ of GDP) and Taxes (\% of revenue).

All selected indicators are quantifiable in order to obtain an objective assessment of competitiveness.

Based on the above-mentioned competitiveness' factors a brief analysis was conducted relating to large Manufacturing enterprises in the South-East region and the results indicate that for the reference period:

- revenue growth (market share growth) of large Manufacturing enterprises in SER has been observed reaching levels of $80 \%$ of total subsector revenues;

- large enterprises are characterized by extensive experience and traditions - 75\% of them have over 10 years of experience (by age);

- and they have the most assets (the largest in size) compared to the size of companies in other Industry sub-sectors - the average size is 40 times larger (7393273 thousand levs in 2017) than the least capital-intensive sector (F in 2017). In the study companies were divided into ones with size up to 100000 thousand levs and ones with size bigger than 100000 thousand levs (6 units), claiming that in terms of this indicator the largest companies have a competitive advantage compared to others resulting in greater economies of scale and scope, greater opportunity for investment and modernization;

- innovations of large Manufacturing enterprises in SER are characterized by major changes. In 2017 the region has a 5\% (39 094 thousand levs) contribution to $R \& D$ expenditures in the overall country's expenditures (the region takes fourth place). The R\&D expenditures of Manufacturing in Bulgaria forms over $35 \%$ of total;

- many companies maintain a good capital structure and only 8 units of all studied need to take measures to improve their financial condition. The results of these units also set high average levels for this indicator for whole sector (above 2). For some of the studied enterprises high levels are acceptable since they are young and one of them has made large investments;

- considering the total liquidity there are again large variations between values of analyzed firms. Although most of the constituent units of the sector are highly dependent on their creditors, they manage to keep acceptable levels (slightly over one). Only 10 companies are overpriced;

- in terms of turnover of total assets and profit margin indicators, the sector has the highest turnover of total assets (in over 90\% of enterprises) compared to other industry sectors but also has the lowest profit margins which were expected since in most productions the increase in production costs outstrips the increase of price;

- labour productivity is a key indicator in terms of measuring competitiveness and the greater its value is the stronger the competitive advantage has one enterprise over the others. For the reference period Manufacturing ranks second in terms of output per employee compared to other Industry subsectors. Only 12 companies have a productivity over 100 000 levs per person, mainly those with a size exceeding 100000 thousand levs resulting in growth and increased market share and profitability;

-SER export-generated revenues accounted for about $50 \%$ of total revenues for the period and were generated only by 40 large Manufacturing enterprises which do export (5 of 45 large enterprises do not export);

- in Manufacturing the levels of profitability are negative throughout the period. Claims about this indicator can hardly be deduced. The reason here lies in the large relative share of losses of two major leading regional companies in recent years. The average return on assets in manufacturing in the region over the period 2010-2017 varies by $+/$ - limits reaching level of $0.18 \%$ in 2017. Nevertheless, comparing the companies' profitability with the sector's average profitability over the period it is observed that the majority of 
enterprises (60\%) maintain sustainable competitive advantages mediated by the profitability of assets which is a satisfactory result at the regional level.

As already mentioned, there are different perceptions about nature and scope of competitiveness as a category arising from the unequal understanding by researchers about the number, composition and origin of sources of competitive advantages. Consequently, different methodologies are proposed to investigate the multidimensional category.

In this study models and methods that were applied are easier to understand and interpret and they considered the actual level of competitiveness of an individual economic unit and the opportunities for its improvement. Such methods are the Biserial Correlation and Optimal Binning that were applied as related methods for assessing firm competitiveness. The choice of these methods was also dictated by the ease of application and interpretation, as well as by the lack of a uniquely established methodology for examining the firm's competitiveness and the dichotomous nature of some of the observed variables (it should be noted that the use of dichotomous variables has a very immediate and easy to understand economic interpretation as a result of reducing the answers to YES and NO). The methods can be applied to panel data. Naturally, these methods have their advantages and disadvantages.

The choice of Biserial Correlation is dictated by its advantages as a method when the type of correlation coefficient must be select. In this case, the Pearson, Spearman, Phi, Phi correlation coefficients, the point correlation coefficients is unsuccessful due to differences in the scales measured. Considering the available information for the study, the biserial correlation coefficient, in this case, is a suitable measure for several reasons:

- one scale is artificially dichotomous - due to the multidimensionality of competitiveness, and the other is interval;

- the obtained biserial correlation coefficients between each indicator (factor-cause) and the dependent variable (competitiveness) determine the strength, direction and significance of the relationship between firm competitiveness and factor influences;

- the results obtained are easy to interpret.
The biserial (two-series) correlation coefficient is calculated by the formula:

$r_{t b}=\frac{\overline{x_{1}}-\overline{x_{0}}}{\sigma_{x}} \sqrt{\frac{n_{1} \times n_{0}}{N(N-1)}}$

where: $\overline{x_{1}}, \overline{x_{0}}$ are the arithmetic mean of the interval scale feature values;

$\mathrm{n}_{1}, \mathrm{n}_{0}$ - the number of units, respectively, of the first group with the value 0 on the dichotomous scale and the second group with the value of 1 ; $\mathrm{N}$ - is the total number of units, i.e. $\mathrm{N}=\mathrm{n}_{1}+\mathrm{n}_{0}$ The coefficient can receive positive and negative values, i.e. to vary from 0 to $+/-1$.

In order to detail the results of Biserial Correlation, the Optimal Binning method was applied which divides the values of the explanatory variables into categories that allow a good distinction between observations and determination of the boundary levels of the factors determining the firm's competitiveness to be made.

The benefits of using Optimal Binning are:

- the method allows missing data and other special calculations to be included in the model;

- controls or mitigates the effects of extreme values on the model;

- resolves the issue of different values among the characteristics which make the weights of the coefficients in the final model comparable.

In the firm-level competitiveness study, a Biserial Correlation with the Optimal Binning were applied on sectoral data by calculating the biserial correlation coefficients between competitiveness (1/0) and each of the explanatory variables and determining the significance, direction, and strength of the correlations.

The method of Optimal grouping or division of each predictor's values at intervals in which the discrimination of competitive/noncompetitive firms is most pronounced is applied. In this sense, intervals are defined for the values of the attribute and in each interval values of competitive or non-competitive companies prevail.

\section{RESULTS AND DISCUSSIONS}

The analysis began with a description of the main characteristics of the sectoral quantitative panel data using descriptive statistics (Table 3). The results showed that companies in the 
sector had a high labour productivity and a high rate of innovation creation and use but also had high dependency on lenders, low liquidity, lower profit margins, and return on assets. Many extreme values of the indicators "turnover of total assets", "capital structure" and "labour productivity" were recorded vary considerably due to the variety and specificity of the type of production and the size of the individual units considered in the totality.

Table 3. Biserial Correlation in Manufacturing with each of the indicators

Competitiveness $(1=$ competitive; $0=$ non-competitive $)$

\begin{tabular}{|l|l|l|l|}
\hline $\mathbf{n = 3 1 5}$ & $\begin{array}{l}\text { Biserial } \\
\text { correlation coefficient }\end{array}$ & $\begin{array}{l}\text { p-value } \\
\text { (Sig. 2-tailed) }\end{array}$ & Dependency level \\
\hline Age & $.200^{* *}$ & .003 & Weak \\
\hline Innovation & .091 & .177 & Weak and insignificant \\
\hline Capital structure & -.109 & .107 & Weak and insignificant \\
\hline Turnover of Total Assets & $-.137^{*}$ & .042 & Weak \\
\hline Profitability & $.161^{*}$ & .016 & Weak \\
\hline Total Liquidity & -.072 & .288 & Weak and insignificant \\
\hline Labor productivity & .062 & .360 & Weak and insignificant \\
\hline LOG_Size & $.465^{* *}$ & .000 & Moderate \\
\hline
\end{tabular}

*significance level $0.05, * *$ significance level $0.01, * * *$ significance level 0.001

Source: Own calculation

For the sector, all the indicators studied do not have a clear dependence on competitiveness. This is probably due to a large number of observations. They operate in much diversified economic activities (30). For this reason, large differences were found in the indicators "turnover of total assets", "capital structure" and "labour productivity". The moderate correlation between competitiveness and the company's size should not be underestimated.

Table 4. Optimal Binning of Labor Productivity and Size by Manufacturing for 2010-2017 period Grouping by Labor Productivity

\begin{tabular}{|c|c|c|c|}
\hline \multicolumn{3}{|c|}{ Grouping by Labor Productivity } & \multirow{2}{*}{$\begin{array}{l}\text { Observa } \\
\text { ions in } \\
\text { the } \\
\text { Group }\end{array}$} \\
\hline Values & $\begin{array}{l}\text { Competitive } \\
\text { Value }=1\end{array}$ & $\begin{array}{l}\text { Competitive } \\
\text { Value }=0\end{array}$ & \\
\hline$<8.664$ & 1 & 9 & 10 \\
\hline$>=8.664$ & 304 & 1 & 305 \\
\hline Total & 305 & 10 & 315 \\
\hline
\end{tabular}

For firms with Productivity below $8.664,90 \%$ are noncompetitive

When Productivity is $>8.664,99.5 \%$ of firms are competitive

Source: Own calculation

The results shown in Table 4 indicate that when the size is above 4170 the likelihood of competitiveness is very high and with labour productivity higher than 8.7 there is a very high likelihood of firm competitiveness.

The analysis that was made using the Optimal Binning method for the reference period assumes that the highly correlated factors with firm competitiveness are decisive and interrelated i.e. do not contradict each other.

\section{CONCLUSIONS AND RECOMMENDATIONS}

1. Manufacturing Industry in the South-East region needs to implement measures concerning "debt management" because of the very high dependence on creditors of onethird of the companies in the sub-sector. Here, government intervention could have a positive impact on its growth;

2. There is no generally accepted understanding of how to measure firm competitiveness and it must inevitably be taken into account that the concept of 
"competitiveness" is multidimensional and dynamic. The application of Biserial Correlation as a valuation model combined with Optimal Binning method details the competitiveness at the firm level. It shows the strength, direction and influence of the selected indicators for assessing the firm's competitiveness. Based on these results, the factors determining the competitiveness of a particular company can be systematized and can be reveal the decision-making opportunities that determines effective corporate policy;

3. The models are applicable and can be solved with each information update for each factor individually and collectively for all observed factors. In this way, trends in competitiveness at the firm level not only for Manufacturing but also for all other sectors of the national economy can be studied and forecasted.

\section{REFERENCES}

1. Vukovic, D., Correlation analysis of indicators of regional competitiveness: the case of the republic of Serbia. Economic Horizons, 15(3):201-215, 2013.

2. Martin, L., Westgren, R., and Van Duren, E., Agribusiness competitiveness across national boundaries. American Journal of Agricultural Economics, 73:1456-1464, 1991.

3. Fischer, C. and Schornberg, S., Assessing the Competitiveness Situation of EU Food and Drink Manufacturing Industries: An Index-Based Approach. Agribusiness, 23(4):473-495, 2007.

4. Oral, M., Cinar, U. and Muhittin, H., Linking industrial competitiveness and productivity at the firm Level. European Journal of Operational Research, 118:271277, 1999.

5. Shterev, N., Quantitative Functional Evaluation of the Competitiveness of Business Organizations. Economic alternatives, 3:51-66, 2012.

6. Stherev, N., Research on Determination of the Bulgarian Industrial Enterprises' Competitiveness. The Scientific Papers of UNWE, Sofia, 3: 98-156, 2012.

7. DC, Destination Competitiveness: Development of a Model with application to Australia and the Republic of Korea. An Australian Govt. Report, Australia, October 2001.

8. Iliev, I. Shterev, N. and Blagoev, D., The reindustrialization process - a strategic challenge for the Bulgarian economy.
Journal of Economic Thought, 6:3-14, 2014.

9. Porter, M., The Competitive Advantage of Nations. New York: Free Press, USA, 1990.

10.Porter, M., Competitive Advantage: Creating and Sustaining Superior Performance. The free Press: Ney Work, USA, 1985.

11.Krugman, P., Making sense of the competitiveness debate. Oxford Review of Economic Policy, 12(3):17-25, 1996.

12.Lall, S., Competitiveness, technology and skills. Edward Elgar Publishing, MA, USA, 2001.

13.Buckley, P., Pass, C., and Prescott, K., Measures of international competitiveness: a critical survey. Journal of Marketing Management, 4:175-200, 1988.

14.Powell, T. C., Competitive advantage: logical and philosophical considerations. Strategic Management Journal, 22(9):875888, 2001.

15.Abdallah, O., Evaluation of Competitiveness Indicators in Sudan During the Period (1981 - 2005). Journal of Business Studies Quarterly, 2(3):75-83, 2011.

16.Aghion, P., and Howitt, P., Chapter 2: Growth and quality - improving innovations: an integrated framework. In: Aghion, P., and Durlauf, S., North-Holland (eds.), Handbook of economic growth. 1st ed., USA, Part A, pp 67-110, 2005.

17.Stojcic, N., Hashi, I., and Telhaj, S., Innovation activities and competitiveness: empirical evidence on the behaviour of firms in new EU member states and candidate countries. CASE Network Studies and Analyses, 424, 2011. Available at: http://dx.doi.org/10.2139/ssrn.1825882.

18.Loof, H., Heshmati, A., Asplund, R.,and Naas, S., Innovation and performance in manufacturing industries: a comparison of Nordic countries. SSE/EFI Working Paper Series in Economics and Finance, 457, 2002. Available at: http://swopec.hhs.se/hastef/papers/hastef04 57.pdf.

19.Harrison, R., W., and Kennedy, P., L., A neoclassical economic and strategic management approach to evaluating global agribusiness competitiveness. Competitiveness Review: An International Business Journal, 7(1):14-25, 1997. 
20.Voulgaris, F., and Lemonakis, C., Competitiveness and profitability: The case of chemicals, pharmaceuticals and plastics. The Journal of Economic Asymmetries, 11:46-57, 2014.

21.Frindrik, M., and Szilárd, I., A gazdaság nemzetközi verseny képességének alakulása es a privatizáció. 50 éves a BKE Jubileumi Tudományos Konferencia. Budapesti: Közgazdaságtudományi Egyetem, pp 18811921, 1998. (The development of the economy's international competitiveness and privatization). In: Voulgaris, F., and Lemonakis, C., Competitiveness and profitability: The case of chemicals, pharmaceuticals and plastics. The Journal of Economic Asymmetries, 11:46-57, 2014.

22.Michalet, CA, Competitiveness and Internationalisation, 1981. In: Molina, M., Pino, I., and Rodríguez, A., Industry, Management Capabilities and Firms' Competitiveness: An Empirical Contribution. Managerial and Decision Economics, 25(5):265-281, 2004.

23.Mathis, J., Mazier, J., and Rivaud-Danset, D., La Competitivite Industrielle, 1988. In Molina, M., Pino, I., and Rodríguez, A., Industry, Management Capabilities and Firms' Competitiveness: An Empirical Contribution. Managerial and Decision Economics, 25(5):265-281, 2004.

24.Martin, L., Westgren, R., and Van Duren, E., Agribusiness competitiveness across
DONCHEVA D.

national boundaries. American Journal of Agricultural Economics, 73:1456-1464, 1991.

25.Fischer, C., and Schornberg, S., Assessing the Competitiveness Situation of EU Food and Drink Manufacturing Industries: An Index-Based Approach. Agribusiness, 23(4):473-495, 2007.

26.Bezić, H., Cerović, L., and Galović, T., Changes in the competitive advantages of Croatia's manufacturing industry. Journal of Economics and Business, 29(2):465-487, 2011.

27.Kumar, A., Stecke, K., and Motwani, J., A Quality Index-Based Methodology for Improving Competitiveness: Analytical Development and Empirical Validation. Working Rarer Series - Working Paper 01015, University of Michigan Business School, USA, 1999.

28. Velev, M., Otsenka i analiz na firmenata konkurentosposobnost. Softtreid, Bulgaria, 2004.

29.Ribov, M., Upravlenie na konkurentosposobnostta v turizma, 2003. In: Velev, M., Otsenka i analiz na firmenata konkurentosposobnost. Softtreid, Bulgaria, 2004.

30. Statistical classification of economic activities in the European Community (NACE) 2008. 